\title{
EVOLUTION OF WATERWAYS AND EARLY HUMAN SETTLEMENTS IN THE EASTERN BALTIC AREA: RADIOCARBON-BASED CHRONOLOGY
}

\author{
P M Dolukhanov $1 \cdot$ A M Shukurov $^{2} \bullet \mathrm{Kh} \mathrm{A} \mathrm{Arslanov}^{3} \bullet$ D A Subetto $^{4,5} \bullet \mathrm{G} \mathrm{I} \mathrm{Zaitseva}^{6} \bullet$ \\ E N Djinoridze $^{3} \cdot$ D D Kuznetsov ${ }^{4} \cdot$ A V Ludikova ${ }^{4} \cdot$ T V Sapelko $\bullet$ L A Savelieva ${ }^{3}$
}

\begin{abstract}
Newly obtained radiocarbon measurements are used to suggest that the initial settlement of the northeastern Baltic area was largely controlled by the Ladoga-Baltic waterway in the north of the Karelian Isthmus, which emerged $\sim 11,500$ cal BP and remained in action for $\sim 7000 \mathrm{yr}$. The transgression of Ladoga Lake started $\sim 5000$ cal BP and reached its maximum at $\sim 3000$ cal BP $(\sim 1100-1000 \mathrm{cal} \mathrm{BC})$. The formation of a new outlet via the Neva River led to a rapid regression of the lake that stimulated the spread of farming populations.
\end{abstract}

\section{INTRODUCTION}

The early human movements in the northeastern Baltic area occurred under the background of drastic environmental changes, the most important of which were related to the post-glacial evolution of the Gulf of Finland, Ladoga Lake, and the hydrological network linked to these basins. Series of radiocarbon dates make it possible to correlate the early stages of human settlement with the evolution of waterways in the entire northeastern Baltic area. This was achieved in 2003-2005 in the framework of an INTAS (International Association for the Promotion of Co-operation with Scientists from the New Independent States [NIS] of the Former Soviet Union)-sponsored field project conducted on the Karelian Isthmus and in the Ladoga Lake basin. The aims of the project included the detailed chronological assessment of the following processes:

1. Emergence and duration of the Baltic-Ladoga Strait;

2. Emergence and duration of the Ladoga Lake transgression;

3. Emergence of the Neva River;

4. The effect of changes in the waterways on the subsistence and movements of prehistoric communities.

\section{METHODS}

To investigate this, we have chosen coring and sampling of lake and mire deposits with subsequent high-resolution ${ }^{14} \mathrm{C}$ dating, pollen and diatom analyses. The techniques of pretreatment and ${ }^{14} \mathrm{C}$ measurement have been described elsewhere (Arslanov et al. 2003). The ${ }^{14} \mathrm{C}$ dates were subjected to a statistical analysis with the use of Bayesian methods.

Investigations have been focused on the areas that were considered of key importance for the attainment of our targets. They included a site in the northern part of the Karelian Isthmus, where the earliest evidence of human presence had been acknowledged; the Veshchevo area located on the BalticLadoga watershed; as well as several clearly stratified sites on the Neva River and the southern coastal area of Ladoga Lake.

\footnotetext{
'School of Historical Studies, Newcastle University, Newcastle upon Tyne, NE1 7RU, United Kingdom. Corresponding author. Email: pavel.dolukhanov@ncl.ac.uk.

¿School of Mathematics and Statistics, Newcastle University, Newcastle upon Tyne, NE1 7RU, United Kingdom.

${ }^{3}$ Institute of Geography, St. Petersburg State University, Russia.

${ }^{+}$Institute of Limnology, Russian Academy of Sciences, St. Petersburg, Russia.

${ }^{5}$ Novgorod State University, Novgorod, Russia.

${ }^{6}$ Institute for History of Material Culture, Russian Academy of Sciences, St. Petersburg, Russia.
} 


\section{RESULTS}

\section{Karelian Isthmus}

The earliest evidence of human presence on the Karelian Isthmus came from the site of Antrea-Korpilahti (Figure 1, \#11). At this site, Mesolithic artifacts were found in the sandy silt together with the remains of a willow bark net, objects of antler, bone, and stone (Pälsi 1920). The bark net yielded a calibrated ${ }^{14} \mathrm{C}$ age of $9200-8250$ cal BC (Matiskainen 1989). During the current project, the organicrich gyttya overlying the sandy silt was ${ }^{14} \mathrm{C}$ dated to $5650-5050 \mathrm{cal} \mathrm{BC}$. This site, like those of a later age, was located along a channel through which Ladoga Lake discharged into the Baltic Sea.

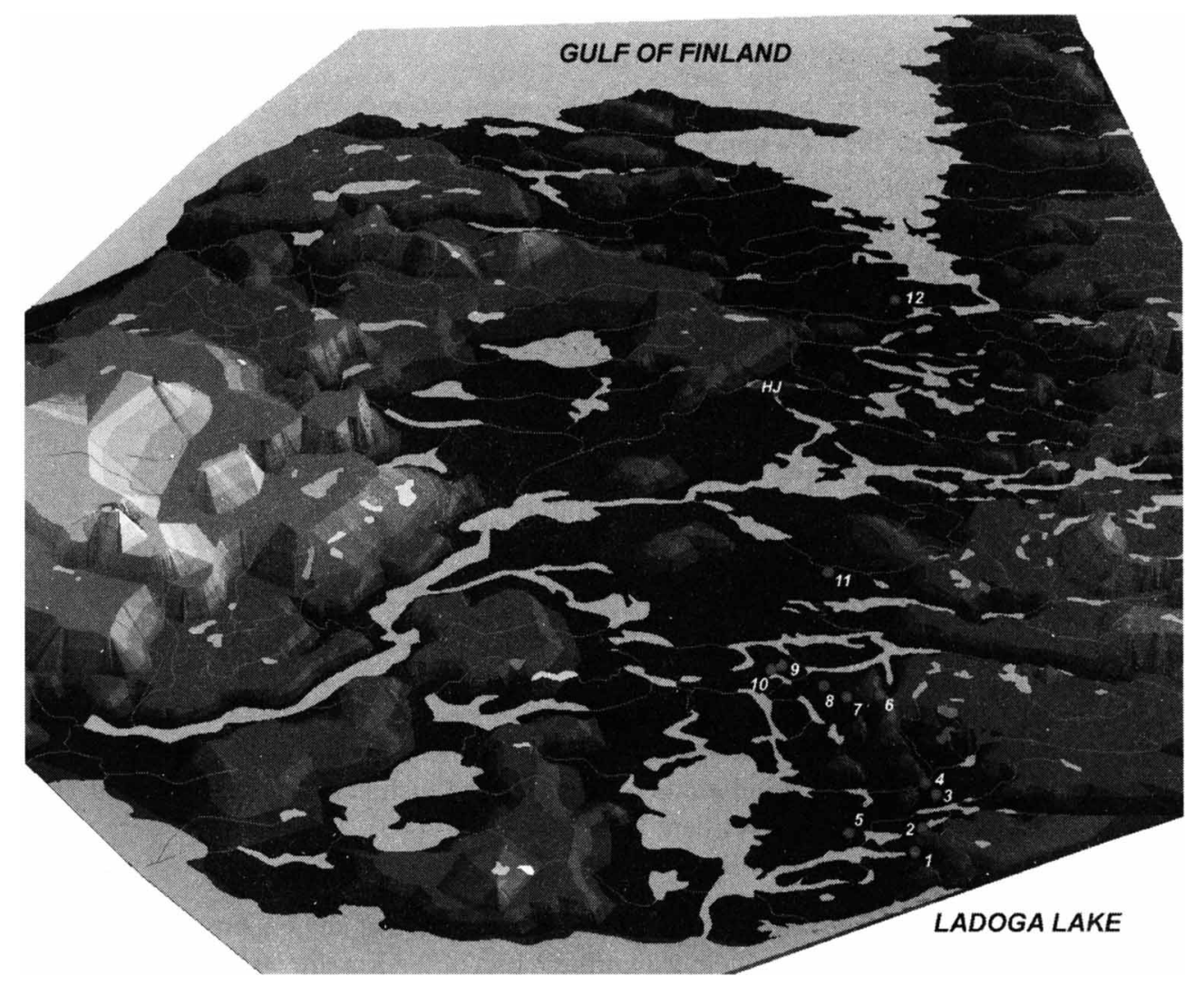

Figure 1 The Ladoga-Baltic Strait and investigated sites, GIS projection

A considerable amount of new evidence has been obtained in the Veshchevo area (formerly known as Heinijoki; "HJ" in Figure 1). The area constitutes the Baltic-Ladoga watershed and includes the "Vetokallio pass-sill" at $15.4 \mathrm{~m}$ above sea level (asl).

Our investigations included the Nizhne-Osinovskoe (NO) raised peat bog, located $5 \mathrm{~km}$ south of the Vetokallio pass-sill and $3 \mathrm{~km}$ west of Veshchevo railway station, with its surface at $23 \mathrm{~m}$ asl. Coring exposed a sequence of lacustrine and mire deposits spanning the entire Holocene.

Fine-grained light-blue silt was identified at the bottom $(800-650 \mathrm{~cm})$, overlain by fine-detritus gyttja at $650-570 \mathrm{~cm}$. The upper part of the sequence consists of mire deposits and includes the following: low mire grass peat with Carex, Equisetum, and Phragmites $(570-550 \mathrm{~cm})$; low mire sedge- 
moss peat $(550-530 \mathrm{~cm})$; low mire sedge peat $(530-450 \mathrm{~cm})$; low mire sedge wood peat $(450-410$ $\mathrm{cm})$; highly decomposed low mire wood peat $(410-170 \mathrm{~cm})$; low mire grass peat with Sphagnum, Phragmites, Menyanthes, and Equisetum (170-140 cm); mesotrophic grass peat and Sphagnum peat of transitional character $(140-110 \mathrm{~cm})$; and slightly decomposed Sphagnum and Scheuchzeria raised bog peat $(110-0 \mathrm{~cm})$.

Thirty-seven ${ }^{14} \mathrm{C}$ measurements covering the last 10,000 yr were obtained from the lake gyttja (depth range $650-570 \mathrm{~cm})$ : Carex peat $(570-450 \mathrm{~cm})$; low mire wood peat $(450-130 \mathrm{~cm})$; mesotrophic grass peat $(130-60 \mathrm{~cm})$; and raised bog peat $(60-0 \mathrm{~cm})$. The dates are presented in Table 1, calibrated with the use of OxCal v 4.0.1 (Bronk Ramsey 1995, 2001, 2007) using the IntCal04 calibration curve (Reimer et al. 2004). Constraints arising from the clear stratigraphic sequence of the samples were included using the Sequence deposition model option of OxCal. The prior and posterior probability distributions are very similar, and all the measurements have shown high levels of agreement (so that none of them had to be discarded) despite a small number of inversions in the uncalibrated dates. This confirms the high quality of both sampling and ${ }^{14} \mathrm{C}$ measurements. The calibrated dates are shown in Figure 2, where the prior (unconstrained) distributions are shown in light gray and the posterior distributions (constrained so that the calibrated age should increase with depth) in black.

Table 1 Lake gyttja ${ }^{14} \mathrm{C}$ ages.

\begin{tabular}{|c|c|c|c|c|}
\hline \multirow[b]{2}{*}{ Lab code } & \multirow[b]{2}{*}{ Type of sample, depth $(\mathrm{cm})$} & \multirow[b]{2}{*}{${ }^{14} \mathrm{C}$ age (BP) } & \multicolumn{2}{|c|}{ Calibrated age } \\
\hline & & & $\mathrm{AD} / \mathrm{BC}$ & $\mathrm{BP}$ \\
\hline LU-5305 & Fine detritus gyttja, 650-655 & $9980 \pm 280$ & $10,700-8600 \mathrm{BC}$ & $11,600 \pm 1050$ \\
\hline LU-5306 & Fine detritus gyttja, 640-650 & $9580 \pm 100$ & $9250-8600 \mathrm{BC}$ & $10,875 \pm 325$ \\
\hline LU-5307 & Fine detritus gyttja, 630-640 & $9440 \pm 70$ & $9150-8450 \mathrm{BC}$ & $10,750 \pm 350$ \\
\hline LU-5308 & Fine detritus gyttja, 620-630 & $9530 \pm 90$ & $9250-8600 \mathrm{BC}$ & $10,875 \pm 325$ \\
\hline LU-5309 & Fine detritus gyttja, 610-620 & $9400 \pm 130$ & $9150-8250 \mathrm{BC}$ & $10,650 \pm 450$ \\
\hline LU-5311 & Fine detritus gyttja, 590-600 & $9300 \pm 130$ & $8900-8250 \mathrm{BC}$ & $10,525 \pm 325$ \\
\hline LU-5313 & Fine detritus gyttja, 570-580 & $8730 \pm 150$ & $8250-7500 \mathrm{BC}$ & $9825 \pm 375$ \\
\hline LU-5315 & Carex peat, 540-560 & $8810 \pm 120$ & $8250-7600 \mathrm{BC}$ & $9875 \pm 325$ \\
\hline LU-5316 & Low mire sedge-moss peat, $530-540$ & $8440 \pm 110$ & $7585-7350 \mathrm{BC}$ & $9417 \pm 117$ \\
\hline LU-5317 & Low mire sedge peat, $510-520$ & $8540 \pm 80$ & $7750-7100 \mathrm{BC}$ & $9375 \pm 325$ \\
\hline LU-5318 & Low mire sedge peat, $490-500$ & $8410 \pm 70$ & $7590-7310 \mathrm{BC}$ & $9400 \pm 140$ \\
\hline LU-5319 & Low mire sedge peat, $470-480$ & $8070 \pm 100$ & $7350-6650 \mathrm{BC}$ & $8950 \pm 350$ \\
\hline LU-5321 & Low mire sedge peat, $450-460$ & $7920 \pm 140$ & $7200-6450 \mathrm{BC}$ & $8775 \pm 375$ \\
\hline LU-5322 & Low mire sedge wood peat, $430-440$ & $7850 \pm 140$ & $7100-6400 \mathrm{BC}$ & $8700 \pm 350$ \\
\hline LU-5323 & Low mire sedge wood peat, $410-420$ & $7990 \pm 70$ & $7080-6680 \mathrm{BC}$ & $8830 \pm 200$ \\
\hline LU-5324 & Low mire wood peat, $390-400$ & $7620 \pm 110$ & $6690-6220 \mathrm{BC}$ & $8405 \pm 235$ \\
\hline LU-5326 & Low mire wood peat, $350-360$ & $7360 \pm 110$ & $6430-6010 \mathrm{BC}$ & $8170 \pm 210$ \\
\hline LU-5327 & Low mire wood peat, $330-340$ & $7270 \pm 90$ & $6270-5980 \mathrm{BC}$ & $8075 \pm 145$ \\
\hline LU-5328 & Low mire wood peat, $310-320$ & $7100 \pm 100$ & $6110-5740 \mathrm{BC}$ & $7875 \pm 185$ \\
\hline LU-5329 & Low mire wood peat, $290-300$ & $7000 \pm 110$ & $6070-5660 \mathrm{BC}$ & $7815 \pm 205$ \\
\hline LU-5331 & Low mire wood peat, $250-260$ & $6580 \pm 80$ & $5640-5360 \mathrm{BC}$ & $7450 \pm 140$ \\
\hline LU-5378 & Low mire wood peat, $240-250$ & $6080 \pm 60$ & $5210-4800 \mathrm{BC}$ & $6955 \pm 205$ \\
\hline LU-5332 & Low mire wood peat, $230-240$ & $5300 \pm 70$ & $4260-3970 \mathrm{BC}$ & $6065 \pm 145$ \\
\hline LU-5333 & Low mire wood peat, $210-220$ & $2880 \pm 70$ & $1290-840 \mathrm{BC}$ & $3015 \pm 225$ \\
\hline LU-5376 & Low mire wood peat, $200-210$ & $2480 \pm 70$ & $790-400 \mathrm{BC}$ & $2545 \pm 195$ \\
\hline LU-5334 & Low mire wood peat, $190-200$ & $2090 \pm 60$ & $360 \mathrm{BC}-\mathrm{AD} 60$ & $2050 \pm 100$ \\
\hline LU-5335 & Low mire wood peat, $170-180$ & $1390 \pm 50$ & AD 540-720 & $1300 \pm 50$ \\
\hline LU-5336 & Low mire grass peat, $150-160$ & $1490 \pm 50$ & AD $430-660$ & $1360 \pm 50$ \\
\hline LU-5380 & Low mire grass peat, $140-150$ & $1090 \pm 60$ & AD 770-1040 & $1000 \pm 60$ \\
\hline LU-5337 & Mesotrophic grass peat, $130-140$ & $950 \pm 60$ & AD 990-1220 & $860 \pm 70$ \\
\hline LU-5338 & Raised bog peat, $90-100$ & $570 \pm 60$ & AD $1290-1440$ & $590 \pm 60$ \\
\hline
\end{tabular}


Table 1 Lake gyttja ${ }^{14} \mathrm{C}$ ages. (Continued)

\begin{tabular}{llclc}
\hline & & & \multicolumn{2}{c}{ Calibrated age } \\
\cline { 4 - 5 } Lab code & Type of sample, depth $(\mathrm{cm})$ & ${ }^{14} \mathrm{C}$ age $(\mathrm{BP})$ & AD/BC & BP \\
\hline LU-5379 & Raised bog peat, 80-90 & $580 \pm 60$ & AD 1290-1440 & $590 \pm 60$ \\
LU-5377 & Raised bog peat, 60-70 & $570 \pm 80$ & AD 1280-1470 & $590 \pm 80$ \\
LU-5374 & Raised bog peat, 40-50 & $180 \pm 70$ & AD 1630-1960 & 200 \\
LU-5342 & Raised bog peat, 30-40 & $210 \pm 80$ & & 200 \\
LU-5373 & Raised bog peat, 20-30 & $70 \pm 50$ & & 200 \\
LU-5343 & Raised bog peat, 10-20 & ${ }^{14} \mathrm{C}=1.22 \pm 0.63 \%$ & Modern \\
\hline
\end{tabular}

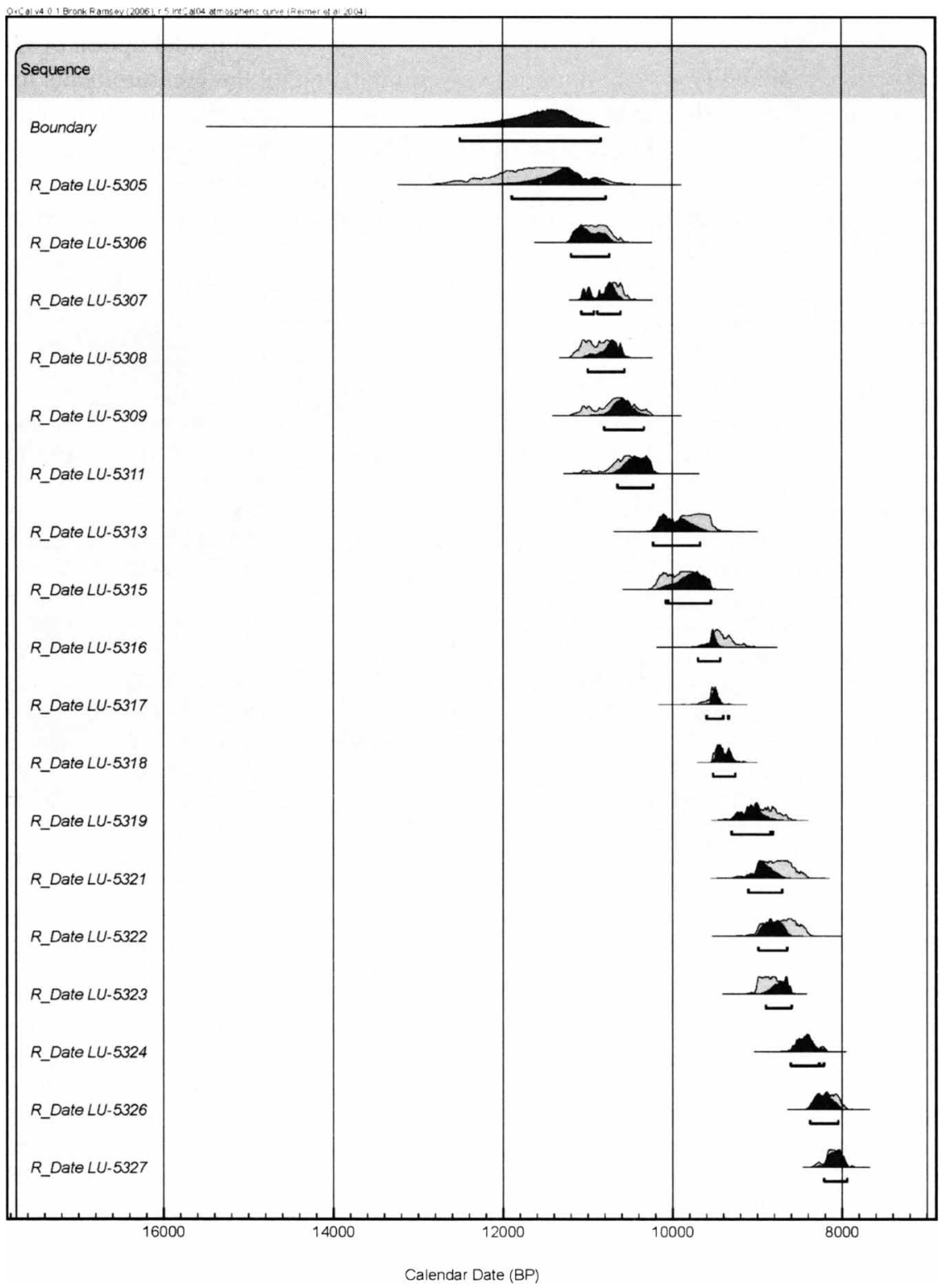

Figure 2 OxCal Sequence deposition model option for NO raised peat bog 
The application of the $U \_$Sequence function of OxCal's deposition models failed, thus demonstrating significant deviation from a uniform deposition rate. The deposition rate can be obtained from the dates of Figure 1 as follows. The middle of each age range obtained at the $95.4 \%$ confidence level, denoted $T_{n}(n=0, \ldots, N$ with $N=30)$, was adopted as a representative age for each depth. For the sake of accuracy, the depth of the top of each layer $z_{n}$ was used in the calculations, with $z=0$ corresponding to the surface. Then, the deposition rate was calculated as $R_{n}=\left(z_{n+1}-z_{n}\right) /\left(T_{n+1}-T_{n}\right)$, with the uncertainty obtained by error propagation as

$$
\delta R_{n}=\left[\left(z_{n+1}-z_{n}\right) /\left(T_{n+1}-T_{n}\right)^{2}\right] \sqrt{\delta T_{n+1}^{2}+\delta T_{n}^{2}}
$$

where $\delta T_{n}$ is the error of the age shown in Table 1 (we have neglected any errors in the depth determinations). Results shown in Figure 3 reveal considerable fluctuations in the deposition rate in the time range $11,000-7000 \mathrm{cal} \mathrm{BP}$, followed by a very low rate at 7000-3000 cal BP, followed by a slight increase during the last $3000 \mathrm{yr}$. A strongly deviating rate at $1340 \mathrm{BP}(1 \pm 1 \mathrm{~cm} / \mathrm{yr})$ is apparently an artifact resulting from the fact that the 2 calibrated dates involved are very close to each other (although the uncalibrated dates differ by $\sim 120 \mathrm{yr}$, the calibrated ones only differ by $20 \mathrm{yr}$ ) and should be ignored.

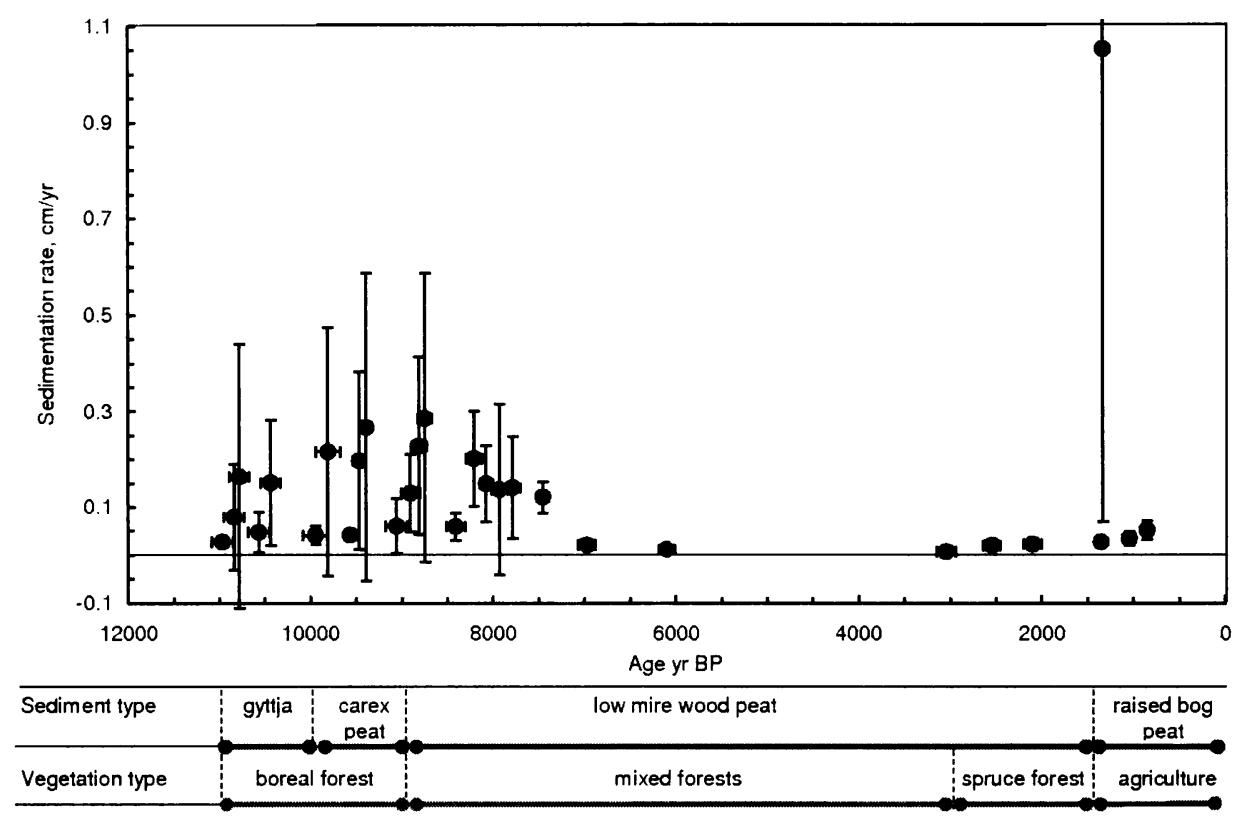

Figure 3 Sedimentation rate, as a function of time, for the NO raised peat bog. The lower part of the figure indicates the sediment vegetation types (the latter based on pollen analysis as described in the text).

Several pollen zones have been distinguished resulting from the pollen analysis of the NO sequence (Figure 4):

- NO-1 (700-665 cm; fine-grained light-blue silt; >11,600 cal BP): light birch forest with patchy occurrences of periglacial steppe-tundra;

- NO-2 (665-555 cm; fine-detritus gyttja; 11,000-9800 cal BP): boreal-type pine and birch forests with a Cyperaceae-Poaceae underwood;

- NO-2b (555-515 cm; Carex peat; 9800-8500 cal BP): birch and pine forests with hazel with a small admixture of elm, and hazel in the underwood; 


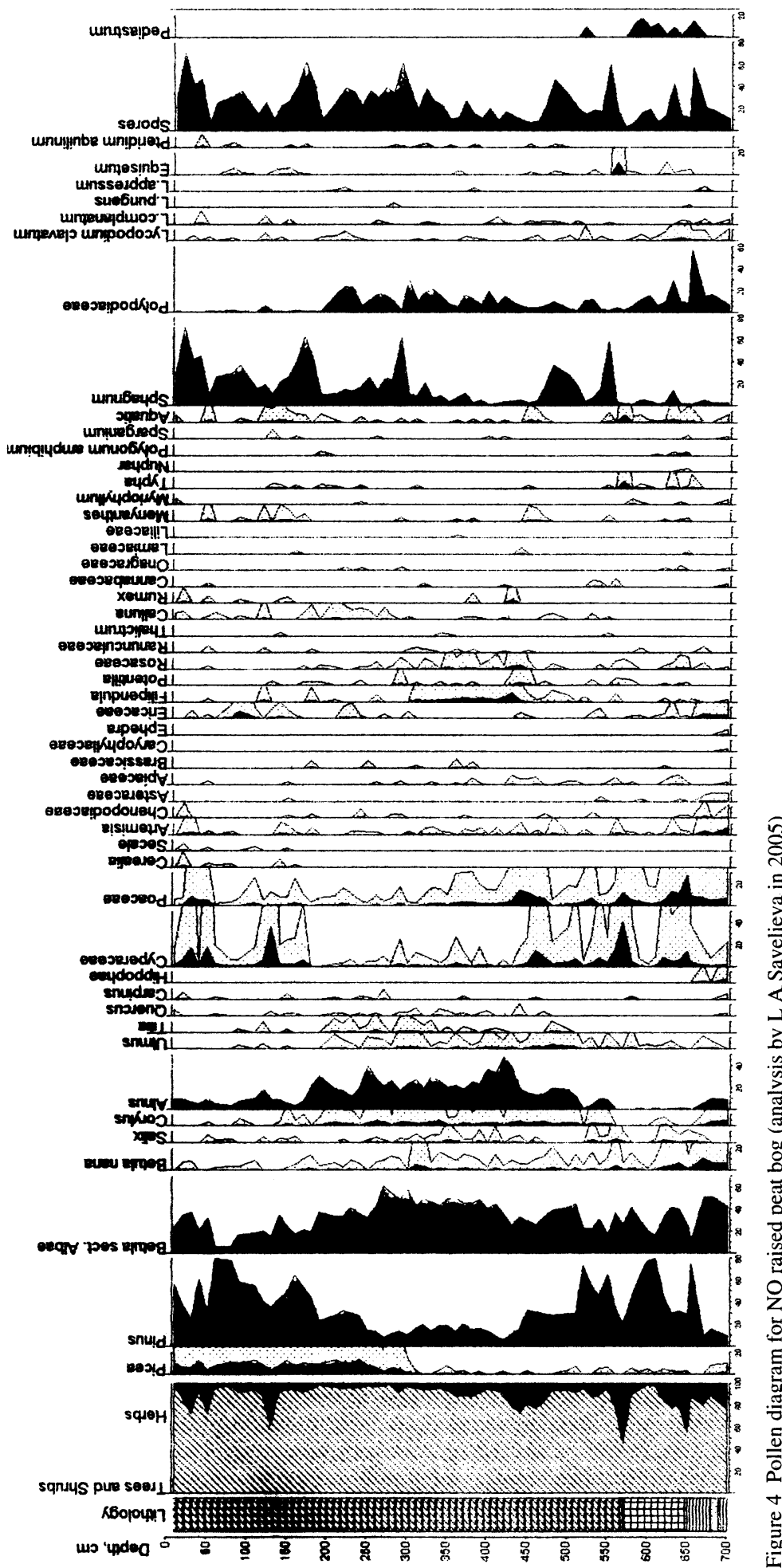


- NO-3a (515-435 cm; Carex peat; 8500-8700 cal BP): mixed forests consisting of birch, pine, and alder with an increasing admixture of elm and hazel;

- NO-3b (435-315 cm; low mire wood peat; 8700-7900 cal BP): mixed forests consisting of birch and alder forests with broad-leaved species and hazel present;

- NO-3c (315-240 cm; mire wood peat; 7900-7000 cal BP) birch and alder forests with rapidly expanding spruce;

- NO-4 (240-180 cm; mire wood peat; 7000-1300 cal BP) boreal-type forest with an increased presence of spruce and the gradual decline of broad-leaved species;

- NO-5a (180-125 cm; mire wood peat; 1300-900 cal BP): boreal pine forest alternating with spruce and birch, and increased open areas, apparently due to agricultural activities;

- NO-5b (125-55 cm; mesotrophic peat; 900-200 cal BP): boreal pine forest alternating with spruce and birch, and increased open areas, apparently due to agricultural activities, as witnessed by the occurrence of cereal pollen;

- NO-5c (55-0 cm; raised bog peat; 200-0 cal BP): open pine forest with the appearance of secondary birch forest.

The diatom analysis performed for the samples from the lower part of the sequence has identified several distinct assemblages (Figure 5):

- $800-780 \mathrm{~cm}$, fine-grained light-blue silt. The assemblage is dominated by the freshwater planktonic species Aulacoseira islandica subsp. helvetica, with rare valves of other freshwater species; Baltic Ice Lake (BIL);

- 780-750 cm, fine-grained light-blue silt. The assemblage is dominated by the freshwater species Gyrosigma attenuatum; a short-lived regression of BIL, the Gyrosigma stage;

- 750-700 cm, fine-grained light-blue silt. The samples are dominated by brackish-water species, Diploneis dydima, D. stroemii, D. smithii et var., Opephora marthyi, Mastogloia spp., Campylodiscus echeneis. The deposits might be considered as being formed by the weakly saline Yoldia Sea. Rare occurrences of saline species, Thalassiosira gravida, T. excentrica, T. angustelineata, T oestrupii, T. latimarginata, Coscinodiscus sp., Chaetoceros diadema, Actinocyclus curvatulus, Bacterosira fragilis, are apparently redeposited from the interglacial deposits;

- 700-670 cm, fine-grained light-blue silt. The assemblage is dominated by freshwater benthic species, Epithemia zebra, Gyrosigma attenuatum, Opephora marthyi, with rare occurrences of saline species, Mastogloia smithii et var., Diploneis stroemii, Nitzschia tryblionella. The deposits are seen as corresponding to a regressive, freshwater stage of Yoldia Sea;

- $670-640 \mathrm{~cm}$, fine-detritus gyttja ( 11,000 cal BP). The assemblage includes the species adapted to freshwater small lake environment, dominated by Pinnularia viridis, P. mesolepta, G. attenuatum, Epithemia zebra, Cocconeis placentula, Aulacoseira islandica subsp. helvetica. The deposits are apparently formed in a small lake isolated from the Yoldia Sea;

- 640-610 cm, fine-detritus gyttja ( $9800-9700 \mathrm{cal}$ BP). The assemblage is dominated by planktonic freshwater species: Aulacoseira islandica subsp. helvetica, A. italica, A. ambigua; and by benthic species, Cocconeis placentula, Nitzschia vermicularis, Amphora ovalis, Epithemia $z e b r a$. The deposits reflect the maximum rise of Ancylus Lake transgression;

- 610-580 cm, fine-detritus gyttja ( 9800-9700 cal BP). The highest frequencies of Epithemia zebra, followed by E. sorex. A regressive stage of Ancylus Lake;

- 580-560 cm, fine-detritus gyttja ( 9800-9700 cal BP). The assemblage is dominated by a variety of periphytic species: Cocconeis placentula, Fragillaria pinnata, F. construens et var., Epithemia zebra, Eunotia arcus et var. The deposits were formed in a lake isolated from Ancylus Lake. 


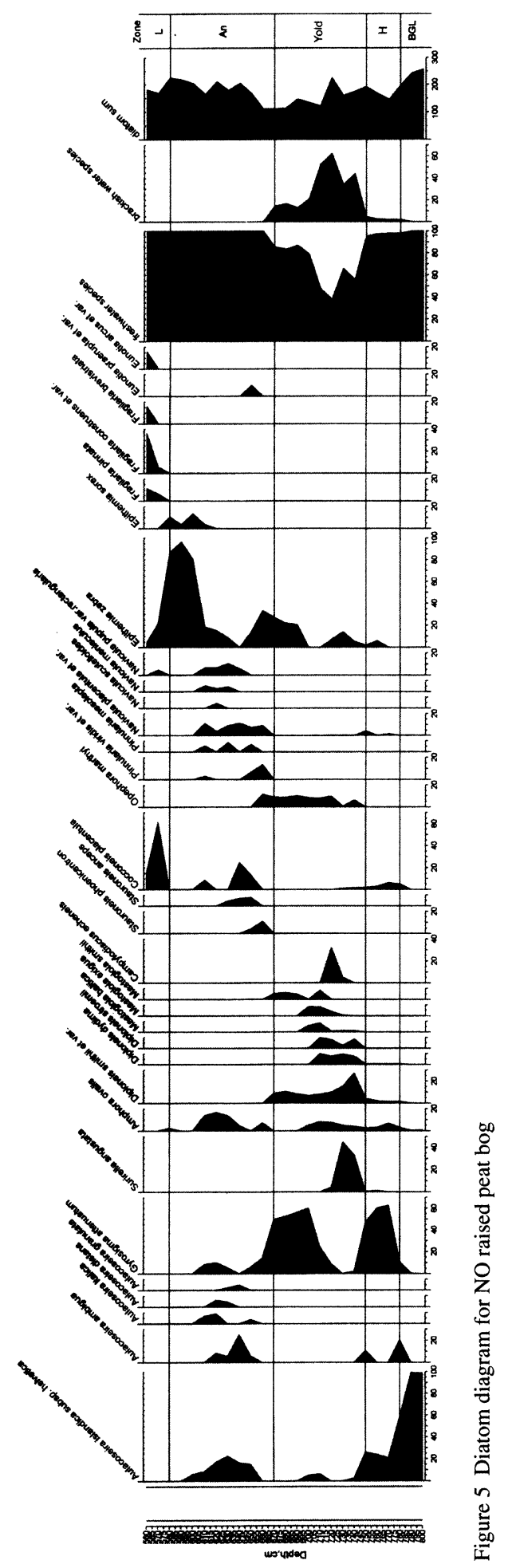


Coring and sampling of bottom deposits was carried out in 2 lakes in the immediate proximity of the Vetokallio pass-sill: Lake Makarovskoye (11.6 m asl; Table 2) and Lake Lamskoye (14.2 m asl; Table 3). The sequences of lacustrine deposits are shown in Tables 2 and $3 .{ }^{14} \mathrm{C}$ measurements have been obtained from the bottom sediments of the both lakes are shown in Table 4 .

Table 2 Sediment description for Lake Makarovskoe core (11.6 m asl).

\begin{tabular}{cl}
\hline $\begin{array}{l}\text { Depth below water } \\
\text { surface }(\mathrm{cm})\end{array}$ & Stratigraphy \\
\hline $0-90$ & Water \\
$90-140$ & Dark-brown, homogeneous, slightly clayey fine-detritus gyttja \\
$140-222$ & Dark-brown, faintly laminated FeS colored gyttja \\
$222-285$ & Dark-brown gyttja \\
$285-291$ & Brownish-gray gyttja clay \\
$291-307$ & Brown, coarse, well-washed sand \\
$307-322+$ & Gray silty clay \\
\hline
\end{tabular}

Table 3 Sediment description for Lake Lamskoye core (14.2 $\mathrm{m}$ asl).

\begin{tabular}{cl}
\hline $\begin{array}{l}\text { Depth below } \\
\text { water surface }(\mathrm{cm})\end{array}$ & Stratigraphy \\
\hline $0-240$ & Water \\
$240-422$ & Dark-brown, homogeneous, slightly clayey fine-detritus gyttja \\
$422-427$ & Gray gyttja clay with sand \\
$427-487+$ & Brown, coarse, well-washed sand with bands of silt \\
\hline
\end{tabular}

Table 4 Bottom sediment ages of lakes Lamskoye and Makarovskoe.

\begin{tabular}{|c|c|c|c|c|}
\hline \multirow[b]{2}{*}{ Lab code } & \multirow[b]{2}{*}{$\begin{array}{l}\text { Type of sample, } \\
\text { depth }(\mathrm{cm})\end{array}$} & \multirow[b]{2}{*}{ uncal. BP } & \multicolumn{2}{|c|}{ Calibrated age } \\
\hline & & & $\mathrm{BC}$ & $\mathrm{BP}$ \\
\hline Le-7006c & $\begin{array}{l}\text { Gyttja, 422-427 } \\
\text { Lake Lamskoye }\end{array}$ & $3560 \pm 160$ & $2400-1500$ & $3950 \pm 450$ \\
\hline Le-7006b & $\begin{array}{l}\text { Gyttja, 422-427 } \\
\text { Lake Lamskoye }\end{array}$ & $3010 \pm 120$ & $1550-900$ & $3175 \pm 325$ \\
\hline Le-7007c & $\begin{array}{l}\text { Gyttja, 417-422 } \\
\text { Lake Lamskoye }\end{array}$ & $3860 \pm 160$ & $2900-1850$ & $4325 \pm 525$ \\
\hline Le-7007b & $\begin{array}{l}\text { Gyttja, 417-422 } \\
\text { Lake Lamskoye }\end{array}$ & $3100 \pm 120$ & $1700-1000$ & $3350 \pm 350$ \\
\hline Le-7008 & $\begin{array}{l}\text { Gyttja, 310-320 } \\
\text { Lake Lamskoye }\end{array}$ & $2620 \pm 230$ & $1400-200$ & $2750 \pm 600$ \\
\hline Le-7008b & $\begin{array}{l}\text { Gyttja, } 310-320 \\
\text { Lake Lamskoye }\end{array}$ & $2620 \pm 220$ & $1400-200$ & $2750 \pm 600$ \\
\hline LE-7309c & $\begin{array}{l}\text { Gyttja, 190-200 } \\
\text { Lake Makarovskoye }\end{array}$ & $2130 \pm 110$ & $400 \mathrm{BC}-\mathrm{AD} 80$ & \\
\hline LE-7309b & $\begin{array}{l}\text { Gyttja, 190-200 } \\
\text { Lake Makarovskoye }\end{array}$ & $3010 \pm 150$ & $1650-800$ & \\
\hline LE-7310c & $\begin{array}{l}\text { Gyttja, } 200-210 \\
\text { Lake Makarovskoye }\end{array}$ & $3810 \pm 120$ & $2600-1900$ & \\
\hline LE-7310b & $\begin{array}{l}\text { Gyttja, 200-210 } \\
\text { Lake Makarovskoye }\end{array}$ & $2720 \pm 170$ & $1350-400$ & \\
\hline
\end{tabular}


Table 4 Bottom sediment ages of lakes Lamskoye and Makarovskoe. (Continued)

\begin{tabular}{lllll}
\hline & & & \multicolumn{2}{c}{ Calibrated age } \\
\cline { 4 - 5 } Lab code & $\begin{array}{l}\text { Type of sample, } \\
\text { depth }(\mathrm{cm})\end{array}$ & uncal. BP & BC & BP \\
\hline LE-7311c & $\begin{array}{l}\text { Gyttja, 260-270 } \\
\text { Lake Makarovskoye }\end{array}$ & $3040 \pm 90$ & $1500-1020$ & \\
LE-7311b & $\begin{array}{l}\text { Gyttja, 260-270 } \\
\text { Lake Makarovskoye }\end{array}$ & $3560 \pm 200$ & $2500-1400$ & \\
LE-7312c & $\begin{array}{l}\text { Gyttja, 270-278 } \\
\text { Lake Makarovskoye } \\
\text { Gyttja, 270-278 } \\
\text { LE-7312b }\end{array}$ & $2960 \pm 100$ & $1420-920$ & \\
\hline
\end{tabular}

The dates for Lamskoye Lake have been analyzed using the deposition model of OxCal with the Sequence function. The prior and posterior probability distributions are very similar, and all the measurements have shown high levels of agreement, with the exception of Le-7007c, which deviates very strongly from the remaining dates and therefore has to be discarded. The calibrated dates are shown in Figure 6, where the prior (unconstrained) distributions are shown in light gray and the posterior distributions in black.

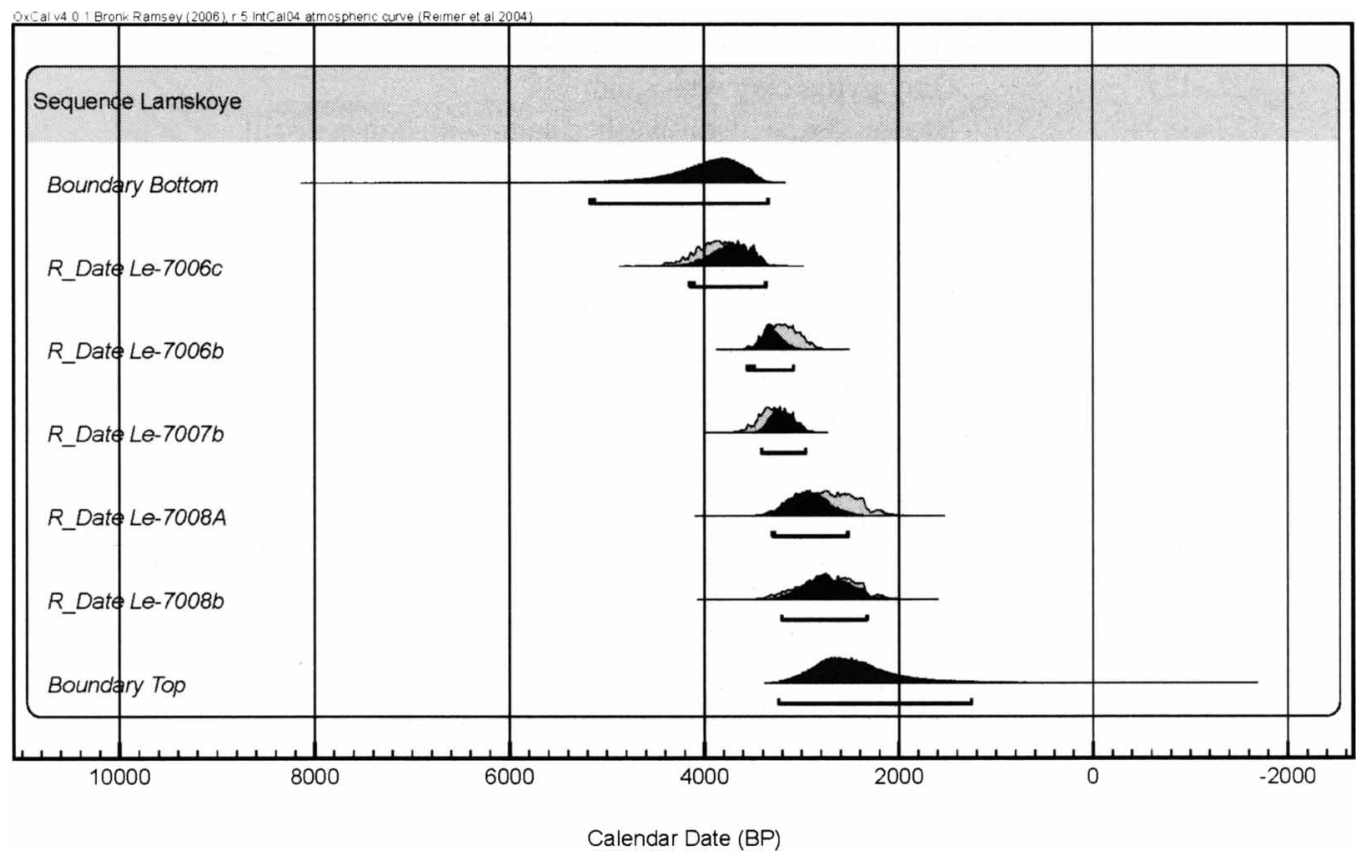

Figure 6 OxCal Sequence deposition model option for Lamskoye Lake

The pollen analysis performed for both sequences shows that the accumulation of gyttya preceded in an environment of boreal pine and spruce forests, with the varying presence of alder and broadleaved species (oak, lime, elm, and ash), culminating in the level postdating one dated to $3010 \pm 120$ $\mathrm{BP}$ and $3500 \pm 160 \mathrm{BP}$. Remarkably, that level signals the presence of Cerealea and indicators of agriculture (notably Plantago). 
The diatom analysis of the bottom silt and sand deposits shows the presence of the species typical of Ladoga Lake, together with other planktonic taxa indicative of meso-eutrophic conditions. The later samples show that the transition from the running water to stagnant conditions was accompanied by an increase in the relative abundance of planktonic taxa, which might be indicative of an increased water depth. The subsequent assemblage shows the disappearance of Ladoga Lake species, suggesting the isolation of the studied lakes from the influx of the Ladoga water. The samples taken from the gyttya show eutrophication (either natural or human-driven), as well as an increase in the accumulation rate, resulting in a decrease in the water depth.

\section{Ladoga Lake-Neva River}

Investigations carried out in 2005-2006 were focused on the detailed chronology of the Ladoga transgression and the establishment of the Neva River. This included the coring and sampling of several key sites along the Neva River and the rivers falling into Ladoga Lake from the south. Two key sites have been investigated along the Neva River: the Nevsky Lesopark (the Neva Forest Reserve) and Nevsky Pyatachok (the Neva Bridgehead).

In the Nevsky Lesopark sequence (Figure 7, \#1), the organic sediments, gyttja, and peat were overlain by the gray silt and fine-grained sand, deposited in the course of the major Ladoga transgression. The following ${ }^{14} \mathrm{C}$ measurements were obtained for the samples of organic sediments (Table 5).

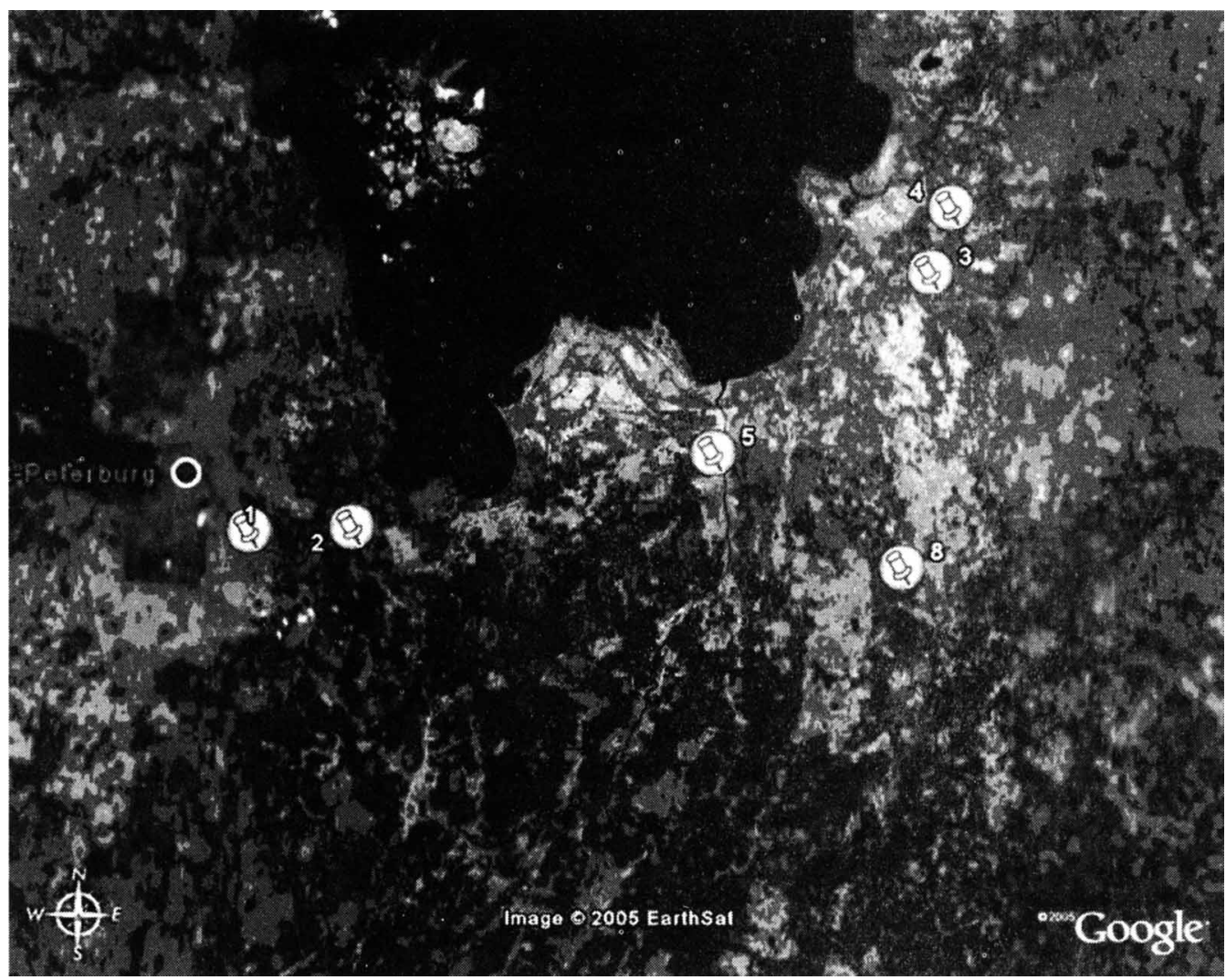

Figure 7 Investigated sites along the Neva River and in the southern Ladoga area (image courtesy Google ${ }^{\circledR}$ ) 
Table 5 Nevsky Lesopark sequence sample ${ }^{14} \mathrm{C}$ measurements.

\begin{tabular}{llllll} 
& & & & \multicolumn{2}{c}{ Calibrated age } \\
\cline { 4 - 6 } Lab code & Depth $(\mathrm{m})$ from below & Material & uncal. BP & BC & BP \\
\hline LU-5443 & 0.95 ; gyttja layer & Wood & $4630 \pm 40$ & $3499-3359$ & $5380 \pm 70$ \\
LU-5449 & $1.12-1.15$; top of gyttja layer & Gyttja & $4540 \pm 70$ & $3363-3101$ & $5180 \pm 130$ \\
LU-5447 & $1.52-1.55$; bottom of peat layer & Peat & $4260 \pm 50$ & $2917-2707$ & $4760 \pm 105$ \\
LU-5444 & $1.15-1.88$; bottom of peat layer & Wood & $4570 \pm 50$ & $3493-3105$ & $5250 \pm 190$ \\
LU-5446 & $1.52-1.55$; top of peat layer & Peat & $3070 \pm 50$ & $1403-1265$ & $3280 \pm 70$ \\
LU-5445 & $1.52-1.55$; top of peat layer & Wood & $2940 \pm 60$ & $1257-1047$ & $3100 \pm 105$ \\
LU-5448 & $1.55-1.65$; bottom of silt layer & Wood & $3120 \pm 50$ & $1487-1317$ & $3350 \pm 85$ \\
\hline
\end{tabular}

These dates have been analyzed using the Sequence deposition model function of OxCal, with the Phase option to isolate 2 groups of samples recovered from similar depths. The date of the boundary between the 2 phases was obtained at about 4000 BP. The upper (most recent) phase boundary, which presumably preceded the maximum rise of the Ladoga transgression, has been estimated to be about 3000 BP (Figure 8).

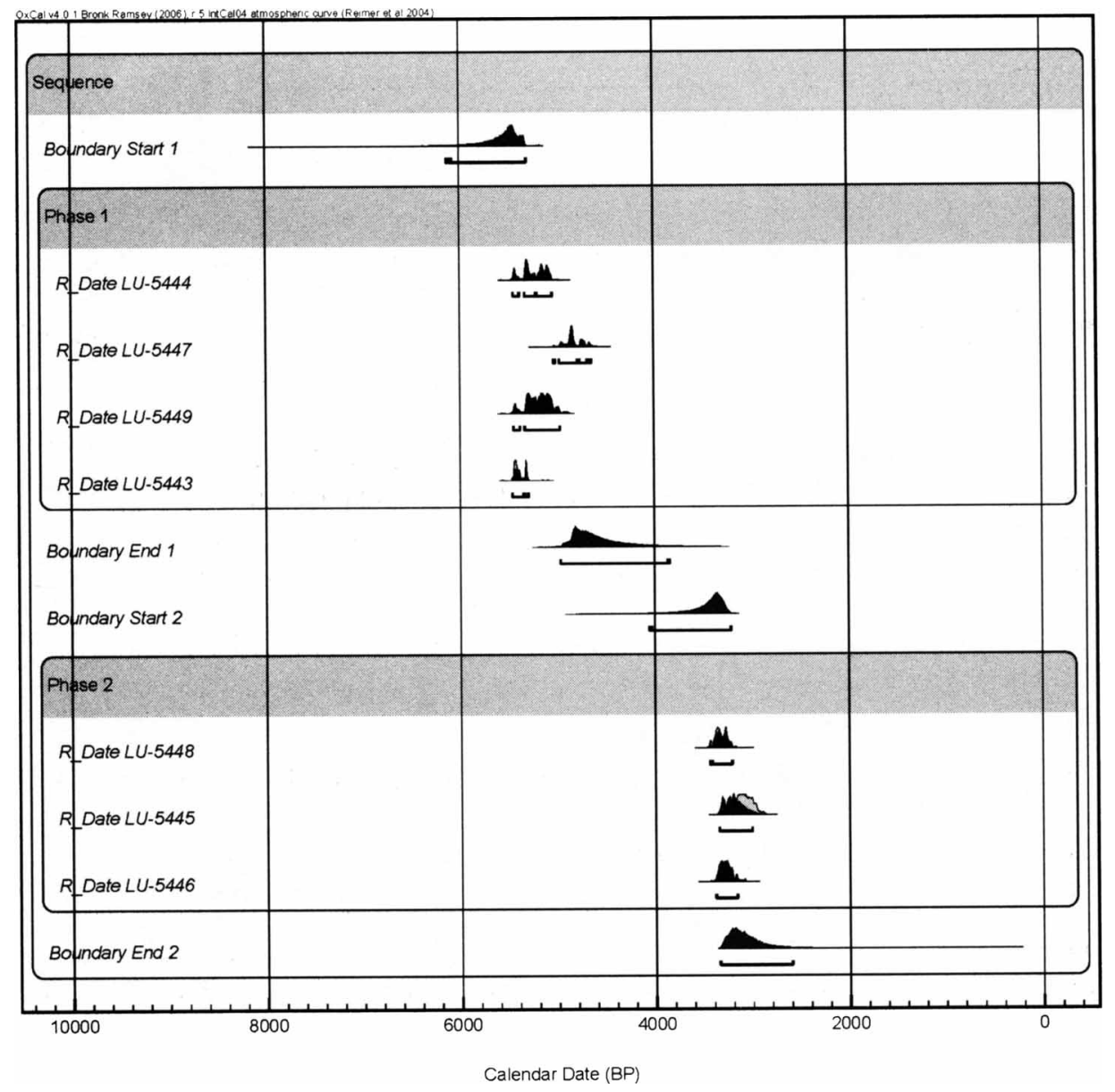

Figure 8 OxCal Sequence deposition model with the Phase option for Nevsky Lesopark 
In the sequence of Nevsky Pyatachok (Figure 7,\#2), the silt apparently deposited during the Ladoga transgression was overlain by the gyttya and peat that had been formed immediately after the breakthrough of the Neva River and the rapid fall of the Ladoga Lake level. The obtained measurements are shown in Table 6.

$\underline{\text { Table } 6 \text { Nevsky Pyatachok sample }{ }^{14} \mathrm{C} \text { measurements. }}$

\begin{tabular}{llllrl}
\hline & & & \multicolumn{2}{c}{ Calibrated age } \\
\cline { 4 - 6 } Lab code & Depth $(\mathrm{m})$ from above & Material & uncal. BP & \multicolumn{1}{c}{ BC } & \multicolumn{1}{l}{ BP } \\
\hline LU-5459 & $0.8-0.82$; bottom of gyttya & Gyttja & $2870 \pm 50$ & $1125-945$ & $2985 \pm 90$ \\
LU-5460 & $0.76-0.78 ;$ gyttja layer & Gyttja & $3560 \pm 50$ & $801-549$ & $2625 \pm 125$ \\
LU-5461 & $0.62-0.64$; peat layer & Peat & $2260 \pm 50$ & $393-209$ & $2250 \pm 90$ \\
\hline
\end{tabular}

Detailed geomorphologic and stratigraphic observations were performed in the river valleys of the Volkhov, Svir, Pasha, and Oyat, south of Ladoga Lake. In the sequence on the left bank of the Oyat River, near the Lenenergo settlement (Figure 7, \#4), organic deposits consisting of peat alternating with gyttja have been found buried under the stratified silt and sand, apparently accumulated in the course of the Ladoga transgression. Several ${ }^{14} \mathrm{C}$ dates have been obtained (Table 7).

Table 7 Oyat River sample measurements.

\begin{tabular}{llllll}
\hline & & & \multicolumn{2}{c}{ Calibrated age } \\
\cline { 5 - 6 } Lab code & Depth $(\mathrm{m})$ from above & Material & uncal. BP & BC & BP \\
\hline LU-5454 & 1.91 ; peat layer & Wood & $4220 \pm 70$ & $2903-2677$ & $4740 \pm 110$ \\
LU-5458 & $2.0-2.2 ;$ gyttja layer & Wood, peat & $4000 \pm 40$ & $2567-2469$ & $4470 \pm 50$ \\
LU-5456 & $2.67-2.7 ;$ gyttja layer, bottom & Wood & $4380 \pm 90$ & $3305-2889$ & $5050 \pm 210$ \\
LU-5453 & $2.7 ;$ peat layer, top & Wood & $5860 \pm 70$ & $4829-4619$ & $6725 \pm 60$ \\
\hline
\end{tabular}

\section{DISCUSSION}

As follows from the earlier studies (Dolukhanov 1979; Subetto 2003), the waterway between Ladoga Lake and the Baltic in the northern lowland of the Karelian Isthmus emerged following the ice-sheet retreat at $\sim 14,000-12,000$ cal BP. During that period, and prior to the catastrophic drop of the Baltic Ice Lake (BIL) at $\sim 11,500$ cal BP, Ladoga Lake remained an easternmost extension of the BIL. In the northern part of the Karelian Isthmus, the highest shoreline BIL reached $\sim 50-60 \mathrm{~m}$ asl. The BIL encompassed Ladoga Lake and covered an entire area of the Karelian Isthmus (except the Central Karelian Heights). The sediments of BIL have been identified in the bottom deposits of Nizhne-Osinovskoe bog sequence.

The opening of the Billingen channel in central Sweden and the drop in the level of the Baltic Ice Lake (11,500-11,000 cal BP) led to the emergence of the weakly saline Yoldia Sea (Arslanov et al. 1996; Saarnisto et al. 2000). The Yoldia Sea reached the Heinijoki area, as weakly saline Yoldia Sea diatom species have been identified in the deposits of Nizhne-Osinovskoe bog.

The land uplift in central Sweden led to the isolation of the Baltic Sea from the ocean and the emergence of the Ancylus Lake at around $9500 \mathrm{cal}$ BP. For about $300 \mathrm{yr}$ (9500-9200 cal BP), the sea level rose by 15-25 m (Eronen 1990; Björck 1995). During the ensuing regression, large expanses of dry land emerged. The waterway connecting Ladoga with the Baltic was still in place, often taking the shape of numerous bays with a labyrinth of islands (Tikkanen and Oksanen 1999). One such 
basin was located in the Heinijoki area, and corresponding deposits were recovered in the sequence of Nizhne-Osinovskoe bog. Following the regression of the Ancylus Lake 9800-9700 cal BP, this basin became isolated and turned into a mire, while the lakes with running water remained at the lower levels.

The ocean's eustatic rise above the threshold in the Straits of Denmark led to the penetration of saline water into the Baltic basin at around 8400-8300 cal BP and the emergence of the Littorina Sea. Its deposits became evident in Finland by 7500 BP (Eronen 1974; Björck and Svensson 1994). Yet, the lack of diagnostic diatom assemblages proves that the Littorina Sea never reached the Heinijoki area.

One notes considerable fluctuations in the sedimentation rate in the time range $11,000-7000$ cal BP. With the establishment of boreal-type forest that prevailed 7000-3000 BP, the sedimentation rate markedly decreased.

The earliest evidence of human settlement in the northeastern Baltic area is attested to at AntreaKorpilahti (11,200-10,250 cal BP), where artifacts were found in the deposits of a channel between the Baltic and Ladoga Lake. This was a major waterway via which the entire area was settled by Mesolithic and Neolithic hunter-gatherers. There is a general increase in population density and sedintism, signalled by intensive pottery-making starting at 5560-5250 cal BC. This may be related to the general increase in biomass and biodiversity, as indicated by the establishment of mixed borealbroad-leaved forests observable in the pollen records.

Saarnisto (1970) has demonstrated that from 5000 cal BP, Saimaa Lake started to drain into Ladoga Lake via the Vuoksa (Vuoksi) River. The resulting influx of fresh water led to the rapid rise of Ladoga Lake and the ensuing Ladoga transgression.

Investigations carried out in Lake Makarovskoye and Lake Lamskoye shed light on the final stages of the Ladoga-Baltic waterway. Following 3100-2600 BP, one may witness a transition from running water to more stagnant conditions in these basins. The disappearance of Ladoga Lake species indicates the isolation of the studied lakes from the influx of the Ladoga water. The eutrophication of these basins as well as the increased rate of sedimentation in NO peat bog following 3000 cal BP may be seen as signatures of agricultural impact, which is further substantiated by the presence of farming-related pollen in the deposits of that age.

Our data, including the reliable series of ${ }^{14} \mathrm{C}$ dates, indicate that the Ladoga transgression in the south reached its peak between 2900-1800 cal BP (1100-900 cal BC). The lake level abruptly fell when a new outflow via the River Neva was formed at $\sim 1000-900 \mathrm{cal}$ BC.

The fall of the lake level opened the way for the agricultural colonization of low-lying terraces of Ladoga Lake and the Volkhov-Ilmen system. This may be exemplified by the Shkurkina Gorka site, located on the 18-m-high terrace on the left bank of the River Volkhov, with the evidence of stockbreeding and early metal-working (Yushkova 2003). A series of ${ }^{14} \mathrm{C}$ dates shows its age as $950-350$ cal BC.

The lower lake levels led to the emergence of a network of agricultural settlements, and, eventually, the establishment of urban-type trade and military centers along the waterway. The peaty soil that was accumulated on the 6-m-high terrace at Staroya Ladoga, prior to the emergence of the fortified hill fort, has ${ }^{14} \mathrm{C}$ ages of $1800 \pm 60$ and $1400 \pm 50 \mathrm{BP}$ (cal AD 319-667). The lowermost strata of archaeological sequence of Staraja Ladoga settlement yielded a ${ }^{14} \mathrm{C}$ age of $1360 \pm 50 \mathrm{BP}$ (or cal AD 
641-761), in agreement with the archaeological estimate (Figure 7, \#5). These dates are shown in Table 8 .

Table 8 Staraja Ladoga settlement sample ${ }^{14} \mathrm{C}$ measurements.

\begin{tabular}{llllll} 
& & & & \multicolumn{2}{c}{ Calibrated age } \\
\cline { 4 - 5 } Lab code & Depth $(\mathrm{m})$ from below & Material & uncal. BP & AD & BP \\
\hline LU-5462 & Base of the lower archaeological & Wood & $1360 \pm 50$ & $641-761$ & $1250 \pm 60$ \\
& layer, 1.2-1.21 & & & & \\
LU-5463 & Top of paleosoil, 1.16-1.2 & Wood & $1400 \pm 50$ & $603-667$ & $1315 \pm 30$ \\
LU-5464 & Top of paleosoil, 0.9-1.0 & Wood & $1800 \pm 60$ & $133-31$ & $1725 \pm 90$ \\
\hline
\end{tabular}

\section{CONCLUSIONS}

The investigations described above have demonstrated the existence of a major Baltic-Ladoga waterway in the Karelian Isthmus that emerged $\sim 9200-8250 \mathrm{cal} \mathrm{BC}$. The predominant location of prehistoric sites in the catchment area proves that this waterway effectively controlled the movements of hunter-gatherer groups during the greater part of the Holocene.

Our data show that a general increase of population density and sedentism, signaled by the beginning of intensive pottery-making at 5560-5250 cal BC, occurred in an environment of increased biodiversity and the establishment of mixed boreal-broad-leaved forests observable in the pollen records.

The data obtained indicate that the transgression of Ladoga Lake reached its peak between 2900 $1800 \mathrm{cal}$ BP (or 1100-900 cal BC) and was immediately followed by the breakthrough of the Neva River and the general fall in the levels of lakes and rivers. The availability of low-lying fertile soils stimulated the rapid expansion in agriculture, evident in the occurrence of farming-related pollen and changes in the sedimentation rate.

\section{ACKNOWLEDGMENT}

This research was sponsored by the INTAS, project 03-51-4261.

\section{REFERENCES}

Arslanov KhA, Tertychnaya TU, Chernov SB. 1993. Problems and methods of dating low-activity samples by liquid scintillation counting. Radiocarbon $35(3)$ : 393-8.

Arslanov KhA, Dzhinoridze RN, Chernov SB, Savelyeva LA, Subetto DA, Tertychanaya TV. 1996. New data on Early Holocene basins of the Baltic on the Karelian Isthmus [abstract]. In: 11th International Workshop on Isotope-Geochemical Research in Baltic Region. Abstracts. 14-16 March 1996, Estonia. p 2.

Björck S. 1995. A review of the history of the Baltic Sea, 13.0-8.0 ka BP. Quaternary International 27:19-40.

Björck S, Svensson N-O. 1994. Östersjöns och Västerhavets utveckling. In: Fredén C, editor. Berg och Jord. Sveriges Nationalatlas. Höganäs: Bra Böcker. p 13842. In Swedish.

Bronk Ramsey C. 1995. Radiocarbon calibration and analysis of stratigraphy: the OxCal program. Radio- carbon 37(2):425-30.

Bronk Ramsey C. 2001. Development of the radiocarbon calibration program. Radiocarbon 43(2A):355-63.

Bronk Ramsey C. 2007. Deposition models for chronological records. Quaternary Science Reviews. (INTIMATE special issue). Preprint. Available online at http://c14.arch.ox.ac.uk/getPreprint.php?File=Bronk Ramsey2007.pdf.

Dolukhanov PM. 1979. Leningrad and Soviet Karelia. In: Gudelis V, Königsson L-K, editors. The Quaternary History of the Baltic. Acta Universitet Uppsalensis Symposia I. Uppsala: Uppsala University. p 11526.

Eronen M. 1974. The history of the Litorina Sea and associated Holocene events. Societas Scientiarum Fennica, Commentationes Physico-Mathematicae 44:79195.

Matiskainen H. 1989. Studies in Chronology, Material 
Culture and Subsistence of the Finnish Mesolithic, 10,000-6000 BP. Helsinki: Iksos. 120 p.

Reimer PJ, Baillie MGL, Bard E, Bayliss A, Beck JW, Bertrand CJH, Blackwell PG, Buck CE, Burr GS, Cutler KB, Damon PE, Edwards RL, Fairbanks RG, Friedrich M, Guilderson TP, Hogg AG, Hughen KA, Kromer B, McCormac G, Manning S, Bronk Ramsey C, Reimer RW, Remmele S, Southon JR, Stuiver M, Talamo S, Taylor FW, van der Plicht J, Weyhenmeyer CE. 2004. IntCal04 terrestrial radiocarbon age calibration, 0-26 cal kyr BP. Radiocarbon 46(3):1029-58.

Saarnisto M. 1970. The Late Weichselian and Flandrian history of the Saimaa Lake complex. Societas Scientiarium Fennicae, Commentationes Physico-Mathematicae 37:1-107.
Subetto DA. 2003. Ozernyi sedimentogenez severa evropeiskoi chasti Rossii $\mathrm{v}$ pozdnem Pleistocene $\mathrm{i}$ Golocene [PhD dissertation abstract]. St. Petersburg: Institute for Limnology. 32 p. In Russian.

Tikkanen M, Oksanen J, Seppä H. 1999. GIS-based mapping of Holocene shoreline displacement history of the Baltic Sea in Finland [abstract]. In: International Union for Quaternary Research, XV International Congress. 3-11 August 1999. Durban, South Africa. Book of Abstracts. p 180.

Yushkova MA. 2003. Raskopki poseleniya rannego metalla Shkurkina Gorka v 2002 godu. In: Machinsky DA, editor. Ladoga, Pervaya Sgtolitsa Rusi. St. Petersburg: Nestor-Istorik. p 12-36. In Russian. 